\title{
THE IMPACT OF INTELLECTUAL CAPITAL AND LEADERSHIP ON THE BUSINESS PERFORMANCE OF COMPANIES
}

\author{
UDC: 005.336.4:005.5 \\ Original Scientific Paper \\ Nikola PETROVIĆ ${ }^{1}$, Dragana SAJFERT ${ }^{2}$, Dragica IVIN ${ }^{3}$ \\ ${ }^{1}$ Republic of Serbia \\ E-mail: petrovic.n26@.gmail.com \\ ${ }^{2}$ Republic of Serbia \\ ${ }^{3}$ University of Novi Sad, Technical faculty “Mihajlo Pupin” Zrenjanin, 23000 Zrenjanin, Đure Đakovića bb, \\ Republic of Serbia
}

Paper received: 27.06.2017.; Paper accepted: 05.10.2017.

\begin{abstract}
This paper gives an overview of the impact of intellectual capital, leadership and knowledge, as values significant for a company which intends to develop and improve itself and be as competitive as possible on the market. Intellectual capital is each individual's asset and an aspect of inexhaustible source of knowledge which cannot be taken away by anyone. One's knowledge should constantly be improved in order to be more competitive on the market. Leadership is one of the processes in which one man, with his influence on the working group, achieves common goals and it represents a way of managing a modern organization. Modern business requires that there is a team of leaders who will transfer their knowledge to employees within the organization.
\end{abstract}

Keywords: Intellectual capital, Leadership, Knowledge, Organization, Information.

\section{INTRODUCTION}

In today's business world, each organization's virtue is the ability to develop and improve itself. Also, organizations need to invest in their employees'knowledge in order to increase efficiency and business productivity. Intellectual capital has a significant role in business environment and movement dynamics of modern business economics. A leader managing an organization has an obligation and responsibility to posses relevant skills, power, ability and influence to lead his employees. Intellectual capital or intangible property can be said to be a strategic activity whose role is to have a positive influence on changes, development and efficiency of an organization. Knowledge can be unavailable or hidden, which means that the wheel is constantly being reinvented, (Tisen et al., 2006).

Leadership deals with changes, starting from generating a vision of the future to gathering people around the idea given in the vision and motivating them to overcome all obstacles encountered on the way to achieving the goal generated in the vision, (Sajfert et al., 2012). Leaders must be motivators of both the company's and team members' advancement and development. Leaders apply modern trends in learning and understanding new knowledge in organizations in order to achieve greater successs, survive and be more competitive on the market. A leader must have high emotional intelligence to align their personal goals with the organizational goals in order to perform the company's tasks, (Sajfert et al., 2011). Leadership implies an approach to people mamagement in an organization based on one person's influence on another person independetly of the formal right to realize that influence, (Bešić et al., 2008). Without influence, leadership does not exist, (Northouse, 2008).

Modern business conditions create huge and unknown changes which every organization faces on a daily basis. Global market brings great challenges and constant changes in business environment. An organization's survival on the competitive market will depend on its ability to adapt to changes. Traditional strategic approach 
implies a hypothesis according to which managers can predict future market trends precisely enough to choose a clear strategic direction just by using the set of analytical tools. On the other hand, when market flows are really turbulent and tend to become chaotic, this traditional approach is marginal and in real life even dangerous for the future of business organization, (Đorđević et al., 2016).

\section{INTELLECTUAL CAPITAL AND KNOWLEDGE MANAGEMENT}

Intellectual capital is a significant strategic activity within an organization whose aim is to positively influence changes in the business operations of an organization. By encouraging all the employees to feel as an important part of the organization, loyalty awareness is raised thus motivating better cooperation among team members while performing their business tasks. Team members gain and share their knowledge within the group in a special way, developing the value of knowledge in a company. Intellectual capital refers to all the knowledge employees in an organization possess. Unlike real or tangible property which consists of land, buildings, equipment etc., intellectual capital is intangible. It refers to employees' knowledge, i.e., human resources. (Sajfert et al., 2005)

An organization should show certain respect, appreciate and value its intellectual capitalproperty and natural resources, data, information, knowledge etc. Knowledge is a virtue necessary for further development of an organization's strategic advantage as its important resource. An individual in an organization is perceived as an active participant who brings their personal qualities and experience to the company. (Sajfert \& Vukonjanski, 2006)

Modern organizations aim to observe business processes as knowledge processes. Creating knowledge includes its further expansion, development, upgrading and its application in the organization. Modern business organizations seek ways to create additional knowledge values through identifying, applying and the use of knowledge in a unique way, and that is a process which is partly science, partly art and partly pure luck. Leaders and managers should make efforts to create and develop explicit knowledge as much as possible, which is, by its nature, collective.
Knowledge introduced into a business operation cannot disappear, unlike an individual (employee) who can easily leave the organization. Explicit knowledge contained in the data bank, information and knowledge of an organization make between 10 and $20 \%$, and by applying knowledge management concept, this part can double up, (Sydanmaanlakka, 2002) . An organization which is constantly learning has greater advantage, i.e., more chances for success and development in the future. The employees should constantly, in a continuous flow, expand their knowledge capacities in order to create better results, where new and expansive ideas are appreciated, valued and fostered.

An organization needs to develop so as not to stay at the same level of services, products or practice which made them successful in the previous period. If you hold on to the same practice, you cannot expect the same amount of success in the future. An organization and its power can be measured by observing its leaders or managers who are capable of improving and developing their previously gained knowledge in a "learning organization". There are, of course, many definitions but it can be said that organizational culture assumes the achieved knowledge and experience which an individual uses in the development process of his/her organizational behavior, (Vukonjanski et al., 2015).

The managers' task is to train people to work together, to make their potentials effective and their weaknesses irrelevant. This is of utmost importance for an organization and it is the reason why management is a crucial, decisive factor. (Drucker, 2006)

\section{Modern business and competition}

In modern business, precise and accurate information distribution is a key feature of an organization. Information can bring an organization to a better position compared to other competitors. One should know how to manage information. Information flow managementproviding the right information for the ones who need it so they can react to it quickly. (Gejts, 2001)

What we call information revolution is in fact knowledge revolution. This further implies that the key for maintaining a leadership position in the economy and technology will be the social position of knowledge experts and social acceptance of 
their values, (Drucker, 2005). Companies are largely facing technological changes, since the environment brings about certain changes. Technological environments are characterized by fast rate of technological changes, allocating large funds to research and development activities, concentrating efforts on making small improvements of the existing solutions and the increasing state regulations in the field of new technologies, (Đorđević \& Ćoćkalo, 2007).

The new organizational logic is, (Tisen et al., 2006):

- Dynamic, ready to learn,

- Information-rich,

- Global,

- Small and large,

- Product/client oriented,

- Team oriented,

- Skill oriented,

- Inclusion focused,

- Lateral, networked,

- Customer- oriented.

An organization must accept new changes in order to apply new logic and act immediately so it can deal with potential problems global market brings at high speed. The challenge is greater now than it was 20 yeras ago due to the following reasons, (Rejnert, 2010):

- New companies are mainly service-based,

- New companies mainly do business in the field of knowledge economy,

- Techno-economic paradigm shifts cause enormous changes,

- The number of allowed mistakes is far smaller than in the past,

- The new paradigm is largely in the prestandardization phase, which makes it impossible to select a winner.

In modern business, an organization must accept new business conditions in its environment, adopt new management processes, especially when it relates to their ability and readiness to respond faster to the competition. In modern business conditions, in company management, business functions stand out particularly. Due to their market orientation, they carry a strategic sign, (Đorđević et al., 2011). They are marketing, quality and research and development, (Đorđević \& Ćoćkalo, 2010).

\section{LEADERSHIP AND MANAGEMENT PROCESS IN A DOMESTIC COMPANY}

Vision is a central component of all great leaders, (Kotter, 1996). A leader is someone who has power, ability and knowledge. It is a person who needs to induce other people to follow him by doing the work he proposes. Leadership means having a certain approach to managing employees in an organization. The influence of one person on other employees regardless of his/her formal right to actually have that influence. A leader possesses the ability and knowledge to create a vision, inspire and motivate others to participate in the realization of the set goals. Six foundations of a leader's power: 1. Power of reward, 2. Natural power, 3. Legitimate power, 4. Referential power, 5. Power of expertise and 6. Informational power, (Sajfert et al., 2007).

A leader can, but does not have to have the formal right to lead employees- employees will simply follow the leader. The process clearly implies that the leader affects the follower, but they affect him as well. It needs to be emphasized that leadership is not a linear, one-way phenomenon, but an interactive one. When leadership is defined in such a way, it becomes available to everyone, i.e. it is not limited to the formally chosen leader in the group (Northouse, 2008). A leader is aware of his position when he has the influence and power to be followed by the employees. He uses his power to successfully achieve the organization's goals and in that case we can call it leadership management. Leaders "do the right things' while managers "do things in the right way". Key qualities of a leader are: communication, innovation, initiative, creativity, vision, flexibility, encouraging changes, determination, leading by example, etc. (Sajfert et al., 2006)

Leaders are the ones who need to possess the ability to lead, customize their approach to the team i.e. the employees in order to achieve the set goals and get the desired results. A leader's job is to make a transformation in his organization. He possesses the knowledge, personality and the power of persuasion, (Deming, 1996). A successful leader will have to define his goals and purpose clearly.He is the leader of the future in the global world which isconstantly changing at the speed of light. He must be a role model to others inside and outside his organization. A leader must have good interpersonal skills, motivation and positive attitude which is the key to the efficiency of doing 
the right things with his team within his company. There are 5 types of behaviour of an effective leader, (Sajfert et al., 2012):

- Planning, coordinating and organizing activities,

- Supervision of subordinate associates,

- Establishing and maintaining good relationships with subordinate associates,

- Establishing and maintaining good relatonship with superiors, associates who are at the same level and external associates,

- Taking responsibility for achieved results, performing the specified obligations and making necessary decisions.

In modern business, organizations want their teams to be built within the organizational structure of the company, so the teams are built by several leaders, as one leader in the organization is not enough. The key to a modern organization is not its own capabilities, but the knowledge and capabilities of the leaders within the company. Leadership in the domestic economy is still tied to ownership, that is, the power deriving from ownership. Also, on the domestic market, the perception of leadership as inherent characteristic prevails, (Bešić et al., 2008). The differences between the leaders of private and public companies reflect the impact of the privatization on the management, (Sajfert et al., 2016).

Main courses of action in the field of education of local managers should be, (Bešić \& Đorđević 2007):

- Education for new conditions of entrepreneurship based on a market mechanism, private property and productivity as a factor of competitiveness,

- Promoting a new concept- the necessity of a struggle for productivity as the basis for survival on the market, market development and development of specific enterprises,

- Permanent learning from the experience of others- continuous application of benchmarking method in order to achieve business excellence.

\section{RESEARCH METHODOLOGY}

\section{Problem and subject of the research}

The problem of research in this paper is intellectual capital. Intellectual capital consists of all the knowledge the employees in an organization possess. There are real and tangible assets such as buildings, land, machines and other tangible things, while intellectual capital is an intangible asset or knowledge that an individual possesses. Intellectual capital consists of the knowledge of a company's employees, that is, the human resources of that organization. The examination of intellectual capital is conducted on "Elitas" Ltd. company, which is also the subject of this research. The company is successful, but there is a desire to examine its intellectual capital as well as to define actions for their improvement.

The examination of this relation is very important for the company itself, first of all in order for the observed state to be identified and improved. In this way, there could be possible improvements and possible courses of action for the top management, with the aim of improving the knowledge of the observed company. This paper will present the synthesis of the research phenomenon of intellectual capital and theoretical findings that should influence the development and success of the enterprise and the economy in Serbia.

\section{Research instruments}

Measuring the impact of intellectual capital in observed company used a questionnaire which is composed of eighteen questions.

1. In your company people are recognized as a key resource for successful business.

2. Employees have the expertise for the work they do.

3. Employees have the necessary work experience for the work they do.

4. Employees have additional expert skills for the work they do.

5. Team work is supported and nurtured by employees.

6. Organization of employees is an important factor for the success of the business.

7. Individual capabilities of employees are continuously monitored.

8. There is a possibility of training and career development of employees for the purpose of achieving business performance.

9. Employees are motivated to improve their knowledge.

10.The company has modern machines and tools for the production of products.

11.Employees use modern ways of communication through information technology.

12.The company invests in the development of new products. 
13. The company invests in contemporary and new ways of making products.

14.My superiors are competent for the work they do.

15. My involvement in business was observed, rated and vauled.

16. My work engagement is well appreciated in relation to how much I have been paid.

17.There is enough time, space and finance to improve the business.

18. Continuous learning is an important factor in the development of the business taken over.

\section{Research questions}

The research is conducted in the section where the intellectual capital is examined in the company in which the research questions are answered and where we cannot know in advance the impact of the intellectual capital in the observed company. In further research in this paper, an examination is carried out where certain influences are observed between intellectual capital and the company in which the examination is conducted on the employees. In this case, a conclusion can be drawn that there is positive and statistical the impact of intellectual capital in the observed company.
RQ1: What is the state (average rate) the imapct of intellectual capital in the observed company?

$R Q 2$ : Is there a difference (average rate) the impact of intellectual capital depending on the respondents' gender?

RQ3: Is there a difference (average rate) the impact of intellectual capital depending on the respondents' age?

RQ4: Is there a difference (average rate) the impact of intellectual capital depending on the level of professional qualification of the respondents?

RQ5: Is there a difference (average rate) the impact of intellectual capital depending on the respondent's work position?

\section{Research results}

The research was carried out at the company "Elitas" Ltd, Belgrade. A total of $\mathrm{N}=34$ questionnaires was collected from the same number of respondents. Given that the company has 35 employees, the cause involved most of the company's employees $(97.15 \%)$ of the effect. In this company there are 9 women and 26 men, 16 of them have SSS and 19 high school/university. The conducted research and its results are shown in a form of a diagram.

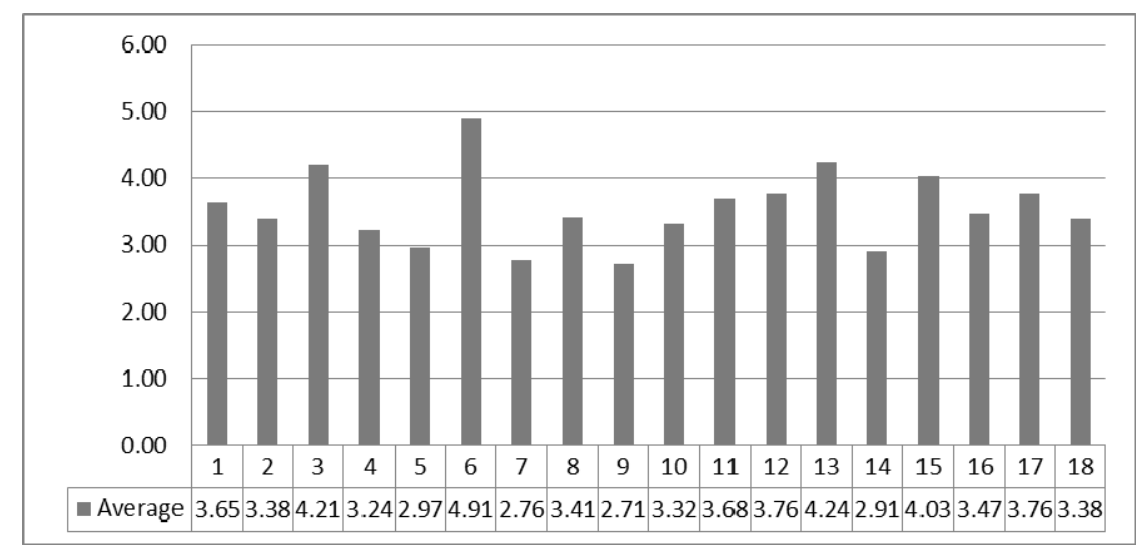

Figure 1: The average rating of the intellectual capital in the company

The results from figure 1 show that the average rate for measuring intellectual capital is higher than the average rate (3,54 for this questionnaire). This shows that the employees in "Elitas" Ltd. company have satisfactory knowledge. The employees are obviously satisfied with the organization and investments in the company. This is very important for both employees and the company. It can be assumed that the employees are satisfied with other aspects which are key factors for the company's success and knowledge improvement.

Results in figure 2 show that to the dimension 'organization of employees' was given the highest average rate by both male and female respondents as well as to investing in new and modern ways of manufacturing products. Both male and female respondents agree that the company invests in the development of new products. Other dimensions 
also got an average rating. The lowest rated dimension is the employees' lack of motivation to improve their knowledge as well as the employees' lack of support for teamwork.

The results in figure 3 show that the dimension regarding good organization of the employees as well as the one regarding investing in new and modern ways of production have the best average value given by all respondents regardless of age. The dimension with low rating is the individual ability which is continuously monitored.

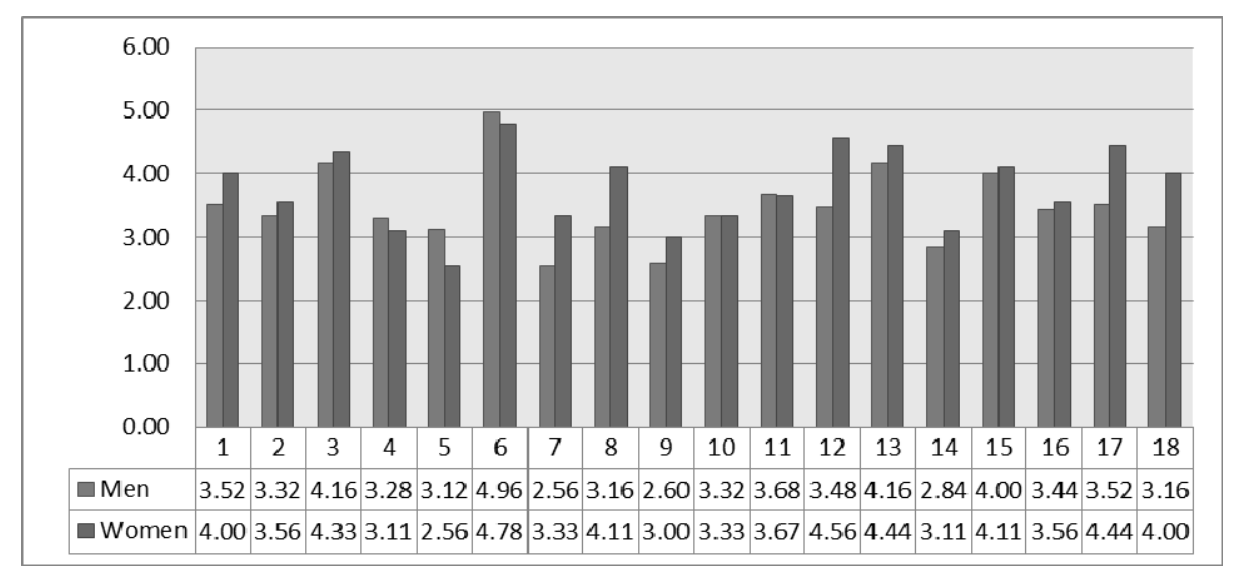

Figure 2: The mean value of intellectual capital for both respondents ' genders

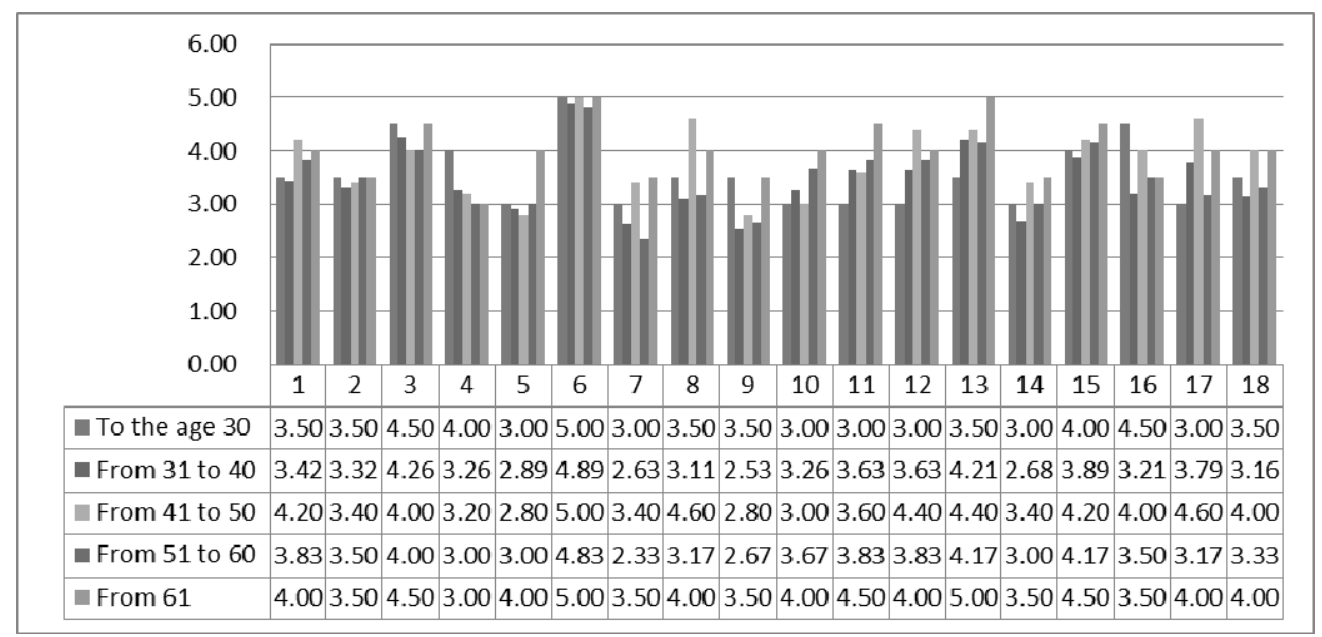

Figure 3: The mean values of intellectual capital by age of respondents

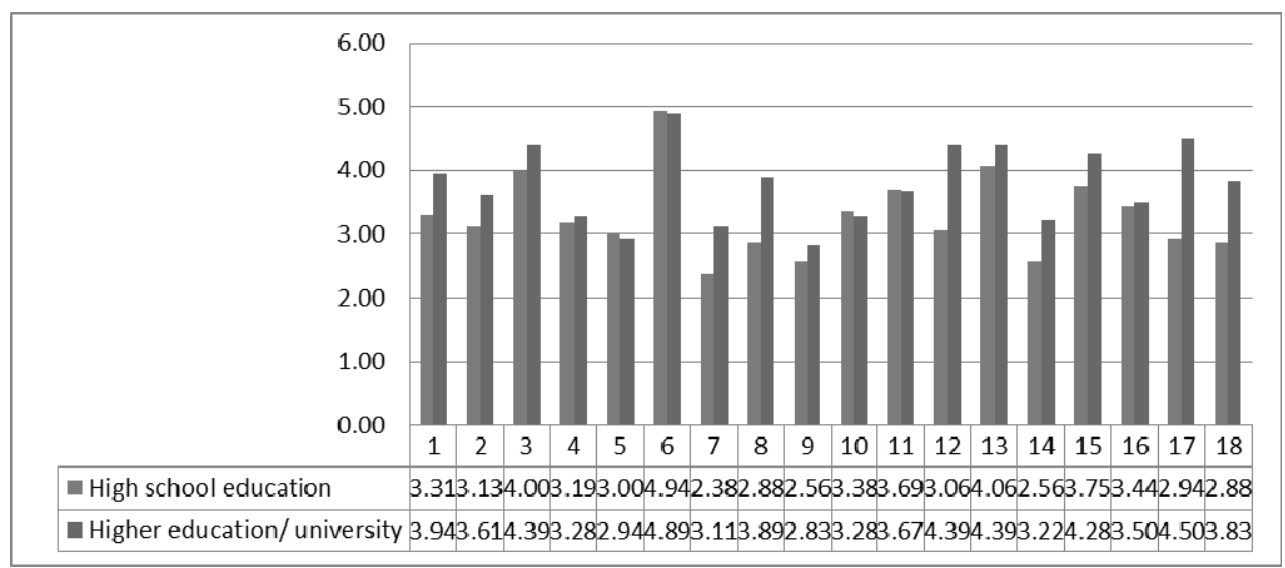

Figure 4: The mean value of the intellectual capital depending on the employees 'professional qualification 


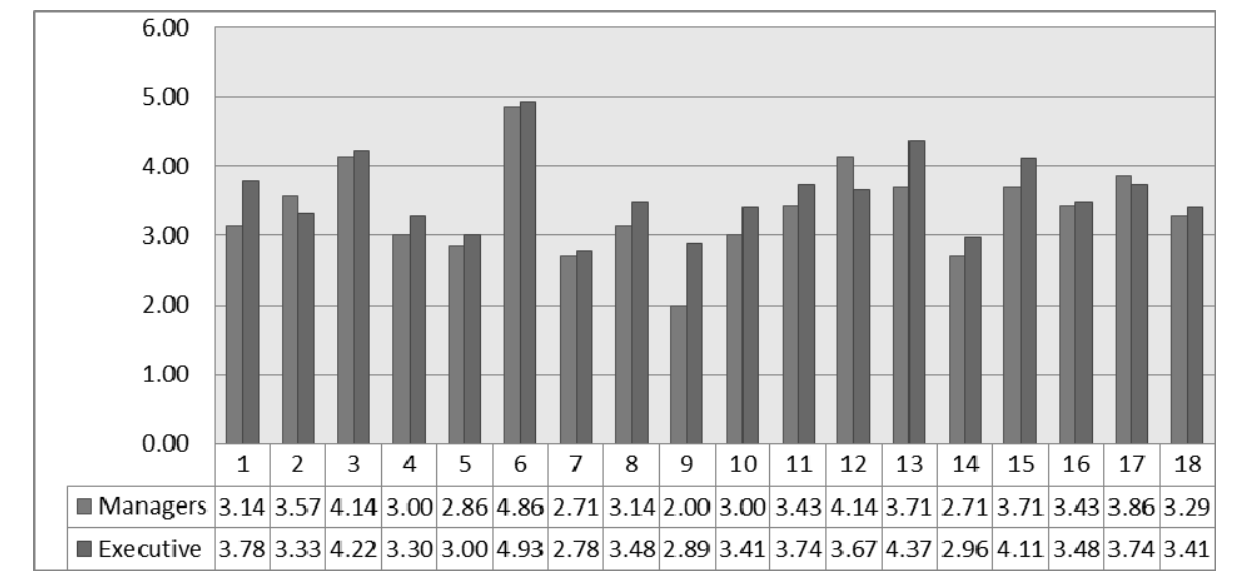

Figure 5: The mean values of intellectual capital depending on the work position

Results from figure 4 show that employees with high school education and with college/university degree have the highest average rate for the dimension regarding good organization of employees, as well as the one regarding investment in new and modern ways of production. The dimension regarding the employees' individual abilities which are continuously monitored has the lowest average rate as well as the one regarding the employees' engagement which was unnoticed, poorly evaluated and appreciated.

Results in figure 5 show that the employees in function manager gave the best average rating to the dimension regarding good organization of the employees and the one regarding investment in new and modern ways of production. Both the employees and their superiors agree on this dimension. The dimension with the lowest average rate is the one regarding employees' individual abilities which are continuously monitored as well as the employees' lack of motivation to improve their knowledge. The lowest average rate in this dimension was given by the manager, while their employees gave a higher rate.

\section{DISCUSSION}

Based on the obtained results, a conclusion can be drawn that the employees at Elitas Ltd. have satisfactory knowledge taking into consideration the respondents' gender, age, professional qualifications and work position in the above mentioned company.

Respondents in this company gave the highest rating to the dimension 6 . the organization of employees is an important factor for successful business and 13. those in new and modern production methods, other dimensions were assessed with a medium grade, the worst evaluated dimensions 9. employees are motivated to improve 5. team work is supported and nurtured by employees, 7. individual ability to be continuously monitored and 15 . employee engagement is poorly recognized, assessed and vauled.

It can be concluded that the research was successfully conducted since all the research questions were responded to. By investing in the employees' knowledge, this company will be able to survive on the market. Also, the knowledge acquired by the employees must be further improved so the company can perform its business tasks even better. There are no results which are bad to the extent that they could endanger the company's successful business operations and employee organization.

Some of these suggestions on how to increase the company's success rate and develop intellectual capital can help the top management improve their business.

- It is necessary to further arouse the employees' interest, so they could improve their knowledge in the best possible way.

- It is necessary to encourage the employees to develop and foster their teamwork in order to improve the company's performance.

- It is necessary for the top management to monitor individual abilities of the employees in order to continuously improve each individual's knowledge.

- It is necessary for the top management to support their employees by noticing, valuing and appreciating their work and awarding it accordingly. 
$\begin{array}{ll}\text { N. Petrović } & \text { The impact of intellectual capital and leadership on } \\ \text { et al. } & \text { the business performance of companies }\end{array}$

\section{CONCLUSION}

Employees and managers will need to be additionally engaged on their own to enhance their knowledge even better and be able to transfer to their colleagues in the company. This paper presents the results of the study of the influence of intellectual capital on the business of the company. In order to keep the company in constant contact with its employees and their impact on the improvement of enterprise production. This type of research should be periodic in order for top management to have the best results to eliminate weaknesses and improve the business of the company.

It is recommended to the company to continue with the good practice of investing in the development of the employees' intellectual capital. The top management should continue with the sustainability of its business practice, detect business problems and focus on solving them in order to improve the company's business performance. We can see that Elitas Ltd. is a successful company, the top management will surely follow the recommendations and guidelines for further improvement of business operations in order to make it as efficient and competitive as possible on the market.

It can honestly be said that nothing happens without a vision, (Sengi, 2003). Nowadays, every company has its leader with a vision, and leaders have their followers who follow them in achieving the vision and setting goals. We can say that intellectual capital and leadership can significantly influence the improvement of a company's business. Ducker (1995) says: "Everyone knows that the second law of thermodynamics states that all work transforms into heat and friction. Drucker's first law states that everything transforms into work, otherwise nothing is done. Much of the work itself becomes heat and friction, but work comes first". Global market will face a deficit of leaders or managers with knowledge, power, persuasive and management skills. It is thus necessary to constantly work on improvement and training of the future leaders and constantly be in search of them. Efficiency is a habit, i.e. a set of established procedures and it is always possible to learn the process, (Drucker, 2006).

\section{REFERENCES}

Bešić, C., \& Đorđević, D. (2007, 12-13 Jun). Benchmarking - knowledge for business excellence (in Serbian). Paper presented at the X International Conference "Quality management and reliability DQM 2007, Belgrade, Serbian.

Bešić, C., Sajfert, Z., \& Jakovljević, L. (2008, 27-29. Maj). Leadership as a prerequisite to improve the competitiveness of domestic businesses (in Serbian). Paper presented at the International Convention on Quality "Quality to European and global integration"JUSK, Belgrade, Serbian.

Deming, E. (1996). New economic science (in Serbian). Belgrade: PS Grmeč - Privredni pregled.

Đorđević, D., \& Ćoćkalo, D. (2007). Quality management (in Serbian). Zrenjanin: Technical faculty "Mihajlo Pupin.

Đorđević, D., \& Ćoćkalo, D. (2010). Fundamentals of marketing . Zrenjanin: Technical faculty "Mihajlo Pupin".

Đorđević, D., Ćoćkalo, D., \& Bogetić, S. (2011). Contemporary trends in management and need for changens in domestic enterprises (in Serbian). Singidunum revija, 8(2), 131-136.

Đorđević, D., Ćoćkalo, D., \& Bogetić, S. (2016). The analysis of marketing concept implementation in domestic enterprises. Journal of engineering management and competitiveness (JEMC), 6(2), 120-128.

Drucker, P. (1995). Management for the future (in Serbian). Belgrade: PS Grmeč - Privredni pregled.

Drucker, P. (2005). Management in a new society (in Serbian). Novi Sad: Asee.

Drucker, P. (2006). The Daily Drucker (in Serbian). Novi Sad: Asee.

Drucker, P. (2006). The effective execututive (in Serbian). Novi Sad: Asee.

Gejts, B. (2001). Business, at the speed of thought (in Serbian). Novi Sad: Prometej.

Kotter, J. P. (1996). Leading Change. USA: Harvard Business School Press.

Northouse, P.G. (2008). Leadership Theory and Practice (in Serbian). Belgrade: Data Status.

Rejnert, E. (2010). Spontaneous chaos (in Serbian). Belgrade: Čigoja štampa.

Sajfert, D., Nikolić, M., Ćoćkalo, D., Đorđević, D., \& Lazić, J. (2016). The leadership and ethical leadership in the serbia metal industry, Industry, 44(1), 27-44.

Sajfert, Z., \& Vukonjanski, J. (2006). Organizational culture (in Serbian). Zrenjanin: Technical faculty "Mihajlo Pupin".

Sajfert, Z., Adamović, Ž., \& Bešić, C. (2005). Knowledge management (in Serbian). Zrenjanin: Technical faculty "Mihajlo Pupin".

Sajfert, Z., Adžić, S., \& Cvijanović, J. (2012). Corporate leadership (in Serbian). Zrenjanin: Technical faculty "Mihajlo Pupin". 
Sajfert, Z., Đorđević, D., \& Bešić, C. (2006). Lexicon management (in Serbian). Zrenjanin: Technical faculty "Mihajlo Pupin".

Sajfert, Z., Đorđević, D., \& Bešić, C. (2007). Management and the power of knowledge sharing (in Serbian). Belgrade: Zadužbina Andrejević.

Sajfert, Z., Stanković, M., \& Istrat, V. (2011). The researsh of the influence of leader emotional intelligence on productivity of serbien companies, Industrija, 39(2).

Sengi, P. (2003). The fifth Discipline - The art and practice of the learning organization (in Serbian). Novi Sad: Asee.
Sydanmaanlakka, P. (2002). An Intelligent Organizatio, Performance, Competence and Knowledge Management, Capstone, Oksford.

Tisen, R., Andrisen, D., \& Depre, F.L. (2006). The knowledge Dividend (in Serbian). Novi Sad: Asee.

Vukonjanski, J., Nikolić, M., Terek, E., Ivin, D., \& Gligorović, B. (2015). The influence of $\operatorname{lmx}$ dimensions on certain dimensions of organizational culture in Serbian companies. Journal of engineering management and competitiveness (JEMC), 5(2), 61-67.

\section{UTICAJ INTELEKTUALNOG KAPITALA I LIDERSTVA NA POSLOVNE PERFORMANSE PREDUZEĆA}

U ovom radu daje se prikaz o uticaju intelektualnog kapitala, liderstvu i znanju kao njegovim vrednostima koji su od važnosti za preduzeće koje želi da se razvija unapređuje i da bude što konkuretnije na tržištu. Intelektualni kapital je vrednost svakog pojednica vid je nepresušnog izvora znanja i to nam niko ne može oduzeti, svoje znanje treba konstantno usavršavati da bi mogli biti konkurentniji na tržištu. Liderstvo predstavlja jedan od procesa u kome jedan čovek svojim delovanjem na radnu grupu ostvaruje zajedničke ciljeve i predstavlja način upravljanja savremenom organizacijom. Savremeno poslovanje zahteva da unutar preudzeća postoji tim lidera koji će svoja znanja da prenesu na zaposlene u organizaciji.

Ključne reči: Intelektualni kapital, Liderstvo, Znanje, Organizacija, Informacija. 